\title{
Pengaruh Metode Kaisa Terhadap Kemampuan Menghafal Surat- Surat Pendek Al-Qur'an Dan Hadits Pada Anak Di Tk Aisyiyah 17 Jasem Ngoro Mojokerto
}

\author{
Try Nur Aliyah ${ }^{1}$ \\ ${ }^{1}$ Universitas Muhammadiyah Sidoarjo, Sidoarjo, Indonesia
}

\begin{abstract}
This study aims (1) to determine the effect of the Kaisa method on the ability to memorize short letters of the Al-Qur'an and hadith in children at TK Aisyiyah 17 Jasem, (2) to determine the influence of the Kaisa method on the ability to memorize short letters. AlQur'an and hadith in TK Aisyiyah 17 Jasem. The research method uses quantitative ex-post facto correlation type. The sampling technique used was purposive sampling. Research data collection techniques are questionnaires and documentation. Test the validity of the questionnaire instrument using expert tests (judges). The data analysis technique used the product moment correlation formula. The conclusion of this study is that (1) there is an effect of the Kaisa method on the ability to memorize short letters from the Al-Qur'an and hadith in children. This is evidenced by the results of the calculation of rcount> rtabel, (0.999> 0.602) then HO is rejected and $\mathrm{Hl}$ is accepted, (2) and the magnitude of the influence seen from the calculation results is 0.999 which has been consulted with the correlation coefficient value at the value of 0.800-1.00 including the category high, so it can be interpreted that the influence of the Kaisa method has a major effect on the ability to memorize short letters of the Al-Qur'an and hadiths in children at Aisyiyah 17 Kindergarten Jasem Ngoro Mojokerto.
\end{abstract}

DOI : https://doi.org/10.15642/jeced.v3i1.687

\begin{tabular}{l} 
Article Info \\
\hline Article history: \\
Received: September 29, 2020 \\
Approved: June 29, 2021 \\
Published online: June, 2021 \\
\hline Keywords: \\
Kaisa Method, \\
Ability to Memorize \\
Short Letters \\
Quran and Hadith \\
\hline
\end{tabular}

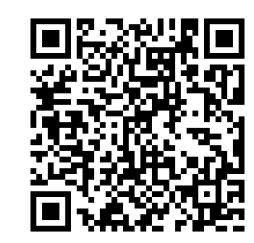

\footnotetext{
Abstrak

Penelitian ini bertujuan (1) untuk mengetahui adanya pengaruh metode Kaisa terhadap kemampuan menghafal surat-surat pendek Al-Qur'an dan hadits pada anak di TK Aisyiyah 17 Jasem, (2) untuk mengetahui besar pengaruh metode Kaisa terhadap kemampuan menghafal surat-surat pendek Al-Qur'an dan hadits pada anak TK Aisyiyah 17 Jasem. Metode penelitian menggunakan kuantitatif ex-post facto jenis korelasi. Teknik sampling yang digunakan yaitu sampling purposive. Tenik pengumpulan data penelitian adalah angket dan dokumentasi. Uji validitas instrumen angket menggunakan uji ahli (judges). Teknik analisis data menggunakan rumus korelasi product moment. Simpulan dari penelitian ini adalah bahwa (1) ada pengaruh metode Kaisa terhadap kemampuan menghafal surat-surat pendek Al-Qur'an dan hadits pada anak. Hal tersebut dibuktikan dengan hasil perhitungan rhitung > rtabel, $(0,999>0,602)$ maka H0 ditolak dan H1 diterima, (2) serta besarnya pengaruh dilihat dari hasil perhitungan yaitu 0,999 yang telah dikonsultasikan dengan nilai koefisien korelasi pada nilai 0,800-1,00 termasuk kategori tinggi, sehingga dapat diinterpretasikan pengaruh metode Kaisa berpengaruh besar terhadap kemampuan menghafal surat-surat pendek Al-Qur'an dan hadits pada anak di TK Aisyiyah 17 Jasem Ngoro Mojokerto.
}

\begin{tabular}{l}
\hline Informasi Artikel \\
\hline Riwayat Artikel \\
Diterima: 29092020 \\
Disetujui: 29062021 \\
Publikasi online: 30062021 \\
\hline
\end{tabular}

\section{Kata kunci:}

Metode Kaisa,

Kemampuan Menghafal

Surat-Surat Pendek

Al-Qur'an dan Hadits 


\section{PENDAHULUAN}

Anak usia dini merupakan sosok yang penuh potensi, memiliki karakteristik yang unik, rasa keingintahuan yang tinggi serta memiliki daya ingat yang tajam. Beberapa orang menyebut fase atau masa ini sebagai golden age karena masa ini sangat menentukan seperti apa mereka kelak jika dewasa, baik dari segi fisik, mental maupun kecerdasan (Habibi, 2018 p.3). Pada usia dini, pondasi utama yang harus dikuatkan pada jiwa anak yakni tauhid dan keimanannya dengan cara mendekatkan anak terhadap Al-Qur'an dan Hadits sebagai pegangan hidupnya.

Al-Qur'an dan Hadits merupakan sumber dasar Islam serta sumber ilmu pengetahuan yang menerangi akal dan menguatkannya.Umat Islam memiliki pegangan yang sangat besar untuk hidup, karena mereka beribadah kapada Allah yang satu, meneladani Nabi yang satu, pedoman kitab suci yang satu serta berkiblat kepada kiblat yang satu pula. Allah subhanallahu wata'ala dan Rasul-Nya pun menjamin keselamatan dunia dan akhirat mereka selama mengikuti petunjuk Allah subhanallahu wata'ala dan berpegang teguh kepada Al-Qur'an dan Hadits.

Sebagaimana firman Allah subhanallahu wata'ala,

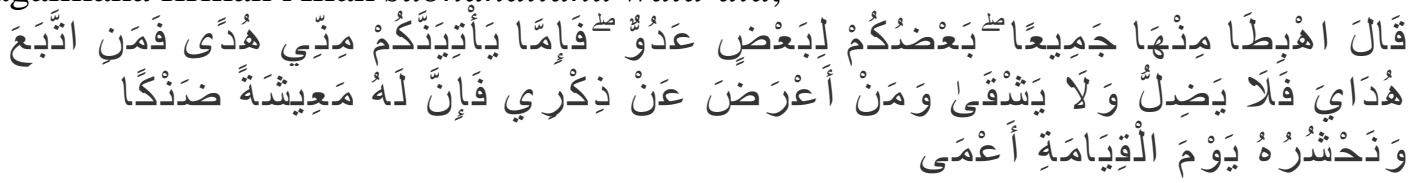

"Maka jika datang kepadamu petunjuk dari-Ku, lalu barangsiapa yang mengikuti petunjuk-Ku, ia tidak akan sesat dan ia tidak akan celaka. Dan barangsiapa yang berpaling dari peringatan-Ku, maka sesungguhnya baginya penghidupan yang sempit, dan Kami akan menghimpunkannya pada hari Kiamat dalam keadaan buta" (Q.S Thaha: 123-124).

Nabi Muhammad shallallahu 'alaihi wa sallam bersabda,

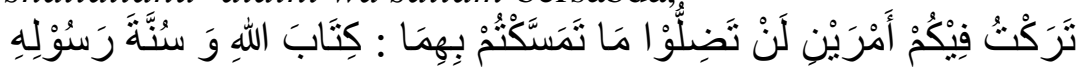

"Aku telah tinggalkan pada kamu dua perkara. Kamu tidak akan sesat selama berpegang kepada keduanya, (yaitu) Kitab Allah dan Sunnah Rasul-Nya."

Al-Qur'an memiliki pengaruh yang besar dalam jiwa manusia yakni mampu menggetarkannya, menariknya dan mendentingkannya. Semakin bersih jiwa manusia, maka semakin besar pula pengaruh Al-Qur'an padanya (al-Baihaqi dan Nashr). Anakanak adalah manusia yang paling bersih jiwanya dan paling suci fitrahnya.Didalam AlQur'an terdapat surat-surat Makkiyah yang memiliki ciri-ciri berisi ayat-ayat yang pendek. Sesuai dengan napas anak-anak yang pendek. Mempersembahkan kepada anak satu pokok pikiran dengan jumlah kata yang sedikit sehingga akan mudah dihafal, tetapi pengaruhnya cukup besar. Diantara pengaruh Al-Qur'an dalam jiwa anak ketika ia menyelaminya (baik dengan membaca maupun menelaah) adalah anak tersebut akan sanggup menyelesaikan berbagai permasalahan, baik menyangkut keyakinan maupun kejiwaan. Perilakunya akan tertata rapi, reaksi keteguhannya akan menjadi tenang dan daya hafalnya menjadi sangat luas.

Anak dapat menghafal Al-Qur'an saat ia memasuki usia tiga tahun (Yasir, 2014, p.101) Ketika manusia dilahirkan, kekuatan hafalannya berada dalam puncaknya, namun kekuatan pemahaman (analisis)nya rendah. Kekuatan hipotesisnya kurang sekali, sedang daya hafalnya justru dalam tingkatan luar biasa (Yahya, 2014, p.55). Masa kanak-kanak adalah masa keeamasan bagi anak-anak untuk menghafal Al-Qur'an. Karena penghafal Al-Qur'an pada masa kanak-kanak tersebut sangat cepat dan akan menghasilkan hafalan yang kuat serta tidak mudah lupa. 
Setiap orang tua pasti menghendaki agar buah hatinya tumbuh menjadi anak yang sehat, cerdas, kreatif mandiri dan bertakwa kepada Allah SWT, kelak agar anaknya menjadi anak yang shalih dan shalihah. Harapan untuk menjadikan mereka yang terbaik, yang dapat menunjang kehidupan mereka di masa depan, atau untuk kebaikan anak itu sendiriserta masih banyak harapan lainnya sebagai orang tua. Untuk mewujudkan hal ini, orang tua perlu mengenal dan memahami dengan baik tentang dunia anak dengan baik.

Orang tua sepatutnya mengajarkan Al-Qur'andan Haditskepada anak-anak sejak kecil. Ini untuk menghantarkannya kepada keyakinan bahwa Allah subhanahu wa ta'ala adalah Tuhan mereka dan ini adalah firman-firman-Nya. Agar ruh Al-Qur'an meresap dalam hati mereka, cahayanya merasuk dalam pikiran dan indera mereka. Supaya mereka mendapat akidah-akidah Al-Qur'an sejak kecil. Juga agar mereka tumbuh dengan kecintaan terhadap Al-Qur'an, keterikatan padanya, menjalankan segala perintah di dalamnya, meninggalkan segala larangan yang terdapat padanya, berperilaku dengan akhlaknya dan berjalan sesuai dengan perintah-Nya.

Dalam kitab shahihnya, Imam Al-Bukhari meriwayatkan sebuah Hadits dari Hajjaj bin Minhal dari Syu'bah dari Alqamah dari Sa'ad bin Ubaidah dari Abu Abdirrahman As-Sulami dari Utsman bin Affan radhiyallahu anhu bahwa Rasulullah shallallahu alaihi wa sallam bersabda,

\section{خَبْرُكُمْ مَنْ نَعَلَّمَ الْقُرْ آَنَ وَعَلَّمَهُ \\ "Sebaik-baik kalian adalah orang yang belajar Al-Qur'an dan mengajarkannya." (H.R.Bukhari)}

Saat ini anak-anak diharapkan hafal Al-Qur'an dan Hadits di usia dini, tetapi orang tua ataupun pendidik lupa untuk menjadi guru terbaik buat mereka. Bukanlah sesuatu yang salah apabila menguatkan hafalan mereka. Banyak tokoh besar yang harum namanya memiliki hafalan yang sangat kuat atas banyak hal sebelum mereka aqil baligh. Tetapi, apabila menggunakan cara yang keliru dalam melatih hafalan akan membuat kemampuan berpikir dan menggunakan akal termatikan.

Salah satu negara yang pernah menerapkan model pendidikan berfokus menghafal adalah Jepang. Ken Watanabe menuturkan bahwa pada tahun 2007 pemerintah Jepang mulai mempertimbangkan peralihan dari pendidikan yang berfokus menghafal (memorization-focused education) kepada pendidikan yang berfokus pemecahan masalah (problem solving focused education) (Watanabe, 2009, p.99).

Kensuke Watanabe menunjukkan perubahan yang terjadi di Jepangbahwa Jepang yang inovatif tersebut lahir dari model pendidikan yang berfokus menghafal. Para pengambil kebijakan yang ada sekarang maupun yang akan menentukan di tahun 2007 merupakan produk pendidikan yang berfokus menghafal. Menghafal itu bekal dasar yang berharga. Selanjutnya mereka didorong untuk memahami betul apa yang dihafalkannya. Dan ini semua ditumbuhkan dengan adab yang tinggi (Adhim, 2015, p.230).

Berbagai riset mutakhir tentang pembelajaran juga menunjukkan bahwa pengulangan yang aktif, terhadap suatu materi, akan menguatkan kemampuan otak dalam mengingat dan menggunakannya sebagai bahan berpikir. Pengulangan dengan cara diucapkan, meskipun dengan lirih (bukan dalam hati), akan lebih mencerdaskan. Hal yang sama juga berlaku untuk membaca; menyuarakan lisan akan lebih bermanfaat dibandingkan dengan membaca dalam hati. Tetapi, mengulang semata-mata untuk menghafal tanpa menghayati maknanya, akan menjadi kotoran data) yang menumpulkan daya nalar kritis maupun kreatif anak. ia juga menyebabkan anak mudah bosan dan 
kehilangan semangat. Jika proses menghafal dilakukan semata-mata karena tekanan untuk mengejar setoran, maka ia akan menjadi beban (Adhim, 2015, pp.228-232).

Berdasarkan hasil observasi di TK Aisyiyah 17 Jasem yang memiliki visi "Cerdas, Mandiri dan Berakhlakul karimah", memiliki waktu pembelajaran tambahan selama 30 menit pada pukul 09.45 - 10.15 WIB yang digunakan untuk pembelajaran TK-Q. TK-Q merupakan program pembelajaran tambahan yang berisi pembelajaran Baca Tulis Qur'an serta hafalan surat-surat pendek Al-Qur'an dan Hadits yang memiliki target ketuntasan sendiri pada setiap tingkat usianya. Program pembelajaran tersebut dilaksanakan setiap hari Senin hingga Sabtu.

TK Aisyiyah 17 Jasem juga memilki program tambahan yakni "Special One Day" yang dilaksanakan setiap hari Rabu dimana anak-anak khusus melakukan kegiatan bakatnya sesuai dengan potensi yang dimiliki oleh masing-masing anak. Diantaranya ada beberapa kelas yang difasilitasi oleh ustadzah-ustadzah yang berkompeten pada bidang tersebut, yakni kelas tahfiz, pildacil, seni rupa dan seni tari. Target akhir pada setiap kelas unggulan tersebut yaitu mereka akan ditampilkan pada setiap acara-acara pertemuan besar misalnya kegiatan parenting, akhirussanah, dan kegiatan diluar sekolah yang menginginkan potensi dan bakat mereka dapat memotivasi khalayak umum serta sebagai bukti bahwa pendidikan anak usia dini sangatlah baik untuk menstimulasi pertumbuhan dan perkembangan mereka baik jasmani dan rohani.

Program TK-Q dan program unggulan kelas Tahfidz Qur'an dan Hadits pada kegiatan "Special One Day" ini diadakan karena sekolah TK Aisyiyah 17 Jasem ini memiliki kurikulum ke-khasan yakni kurikulum Agama Islam dan KeMuhammadiyahan/Aisyiyah. Dibukanya program unggulan ini untuk menggali potensi, minat dan bakat dalam diri anak didik. Hal ini tidak lain untuk menjaga kemutawiran AlQur'an serta menumbuhkan rasa cinta terhadap Al-Qur'an dan Hadits sehingga diharapkan setiap apa yang mereka lakukan mulai dari bangun tidur hingga tidur kembali selalu berdasarkan kepada Al-Qur'an dan Hadits sehingga merekaakan diberi keselamatan dan keberkahan dalam hidupnya.

TK Aisyiyah 17 Jasem ini sangat getol dalam mengembangkan kemampuan menghafal surat-surat pendek Al-Qur'an dan Hadits agar anak dapat mencintai Al-Qur'an dan memahami makna didalamnya. TK Aisyiyah 17 Jasem menginginkan anak didiknya menjadi seorang penghafal yang juga mampu mengamalkan isi Al-Qur'an dan Hadits. Untuk itu, diperlukanlah metode yang efektif dalam mengembangkan kemampuan hafalan untuk anak usia dini yakni melalui metode Kaisa.

Menurut pakar pendidikan anak asal Prancis, Jean Piaget mengatakan, bahwa semua anak memiliki pola perkembangan kognisi yang sama, yaitu melalui empat tahapan; Sensori-Motorik, Praoperasional, Konkret-Operasional, dan FormalOperasional. Untuk anak usia 2-7 tahun berada pada tahapan berpikir "Praoperasional." Pada tahap tersebut anak tidak dapat memahami sesuatu tanpa dipraktikkan terlebih dahulu (Riyanti, 2014, p.1). Jean Piaget juga mengatakan bahwa "pada umur dua tahun keatas anak mulai menggunakan symbol atau tanda untuk mempresentasikan suatu benda yang tidak tampak dihadapannya. Ia dapat menggambarkan suatu benda atau kejadian yang sudah lalu (Suparno, 2001, p.50).

Dengan gerakan, anak menjadi antusias untuk mempelajari dan menghafal AlQur'an dan Hadits dimana setiap gerakan sesuai dengan arti dari ayat yang dibacakan (Salamah, 2018, p.125). Metode Kaisa sangat sesuai diterapkan dalam pembelajaran menghafal Al-Qur'an dan Hadits pada anak. Metode ini sangat berbeda jika dibandingkan dengan metode menghafal yang lain, misalnya metode Talaqqi. Metode Talaqqi adalah 
metode menghafal Al-Qur'an dimana anak hanya duduk diam mendengarkan suara hafalan gurunya lalu anak menirukannya. Sedangkan metode Kaisa adalah metode yang memadukan antara melafalkan dengan benar sesuai dengan kaidah tajwid, gerakan dan arti. Sehingga dalam satu kegiatan sudah mengkombinasikan beberapa aspek kecerdasan.

Peneliti mengambil fokus tentang metode Kaisa dalam mengembangkan kemampuan menghafal Surat-surat pendek Al-Qur'an dan Hadits dikarenakan metode ini bisa dikatakan unik, efektif dan beda dengan sekolah-sekolah PAUD pada umumnya. Di sekolah ini anak difasilitasi khusus dalam hal pengembangan bakat dan minatnya yakni menjadi seorang hafiz melalui kelas Tahfiz pada setiap hari rabu.

Metode ini sangat efektif diterapkan karena dapat memudahkan anak untuk cepat menghafal Al-Qur'an dan Hadits dengan cara yang menyenangkan. Hal ini terbukti saat observasi, anak senang dan tidak mudah bosan saat ia melakukan kegiatan menghafal, anak mampu mengingat kembali apa yang telah ia hafal, anak dapat menyebutkan kembali point-point yang telah dihafal serta ia mampu memberi makna yang telah dihafal. Dengan menerapkan metode Kaisa ini anak dapat menghafal satu target hafalan suratsurat pendek Al-Qur'an dan Haditssesuai kaidah tajwid beserta artinya hanya selama dua minggu. Waktu ini cukup cepat jika dibandingkan dengan metode hafalan yang sebelumnya. Berdasarkan uraian tersebut, mendorong untuk dilakukan penelitian dengan judul "Pengaruh Metode Kaisaterhadap Kemampuan MenghafalSurat - Surat Pendek AlQur'an dan Hadits pada Anak di TK Aisyiyah17 Jasem."

\section{METODE}

Jenis penelitian yang digunakan dalam penelitian ini adalah penelitian kuantitatif jenis korelasional dengan menggunakan metode Ex post facto. Ex post facto adalah penelitian dimana variabel-variabel bebas telah terjadi ketika peneliti mulai dengan pengamatan variabel terikat dalam suatu penelitian (Sukardi, 2003, p.165). Penelitian jenis ex post facto korelasi merupakan suatu penelitian yang melibatkan tindakan pengumpulan data guna menentukan apakah ada hubungan dan tingkat hubungan antara dua variabel atau lebih (Sukardi, 2003, p.166).

Peneliti menggunakan metode penelitian ex post facto untuk menggambarkan penelitian secara empiris dengan dua variabel, yaitu variabel $X$ (metode Kaisa) dan variabel Y (kemampuan menghafal surat-surat pendek Al-Qur'an dan Hadits), permasalahan yang dikaji di dalam penelitian ini adalah "Pengaruh Metode Kaisa terhadap Kemampuan Menghafal Surat-Surat Pendek Al-Qur'an dan Hadits pada Anak di TK Aisyiyah 17 Jasem.”

Dalam penelitian ini yang menjadi populasi adalah peserta didik di TK Aisyiyah 17 Jasem yang berada di wilayah kecamatan Ngoro Mojokerto yang berjumlah 34 siswa. Sedangkan sampel adalah bagian dari jumlah dan karakteristik yang dimilki oleh populasi tersebut (Sukardi, 2003, p.118). Adapun sampel dalam penelitian ini adalah siswa kelas Tahfidz di TK Aisyiyah 17 Jasem yang berjumlah 11 anak.

Teknik sampling pada penelitian ini adalah sampling purposive. Menurut Sugiyono, sampling purposive adalah teknik penentuan sampel dengan pertimbangan tertentu (Sugiyono, 2014, p.99). Adapun kelas yang dipilih sebagai sampel yaitu siswa kelas Tahfiz di TK Aisyiyah 17 Jasem yang berjumlah 11 anak dengan pertimbangan bahwa di kelas tahfidz mereka melakukan pembelajaran bersama tenaga pendidik yang ahli dalam penerapan metode Kaisa.

Pengumpulan data yang akan dilakukan dalam penelitian ini dengan menggunakan metode angket dan metode dokumentasi. Dalam metode angket atau kuesioner digunakan 
angket sebagai alat pengumpul data yang sebelumnya akan diuji validitasnya oleh pakar atau ahli (Uji Judges).

Adapun kisi-kisinya sebagai berikut:

a) Kisi-kisi instrumen Metode Kaisa

\begin{tabular}{cl}
\hline Variabel Penelitian & \multicolumn{1}{c}{ Indikator } \\
\hline & Anak dapat melakukan perumpamaan gerakan \\
Variabel bebas (independen) & Anak dapat memahami perumpamaan gerakan \\
Metode Kaisa & dari arti setiap ayat \\
& Anak dapat menyesuaikan antara gerakan \\
& tubuhnya dengan arti dari ayat \\
& Anak dapat rileks dan merasa senang saat \\
& melakukan kegiatan menghafal \\
\hline
\end{tabular}

b) Kisi-kisi instrumen kemampuan menghafal

Variabel Penelitian

\begin{tabular}{cl}
\hline & $\begin{array}{l}\text { Anak dapat mengingat kembali apa yang } \\
\text { dihafalnya }\end{array}$ \\
Variabel bebas (dependen) & Anak dapat menyebutkan kembali point per \\
Kemampuan menghafal Surat- & $\begin{array}{l}\text { Anan dant yang telah dihafalkan } \\
\text { purat pendek Al-Qur'an dan } \\
\text { Hadits }\end{array}$ \\
& $\begin{array}{l}\text { Anak dapat memahami makna yang dihafalkan } \\
\text { Anak dapat menghafal bacaan dengan fasih dan } \\
\text { sesuai tajwid }\end{array}$ \\
\hline
\end{tabular}

Penulis menggunakan pedekatan kuantitatif dengan data hasil angket, kemudian dianalisis dengan menggunakan analisis regresi linier sederhana.

Untuk mengetahui ada atau tidaknya korelasi antara metode Kaisa terhadap kemampuan menghafal anak, peneliti menggunakan rumus korelasi product moment, sebagai berikut :

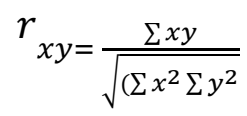

Keterangan:

$\mathrm{r}_{\mathrm{xy}} \quad=$ korelasi product moment

$x \quad=$ skor dari X (soal untuk Metode Kaisa)

$y \quad=$ skor dari Y (soal untuk kemampuan menghafal)

Setelah data dianalisis, untuk menjawab pertanyaan seberapa besar pengaruh Metode Kaisa terhadap kemampuan menghafal Surat-surat pendek AlQur'an dan Hadits anak, yaitu menurut Arikunto dengan cara yang lebih sederhana. Yaitu dengan menggunakan interprertasi terhadap koefisien korelasi yang diperoleh, atau nilai r. Data tersebut dimasukkan pada tabel interpretasi sebagai berikut: 
Tabel 1. Pedoman Interpretasi Koefisien Korelasi

\begin{tabular}{cc}
\hline Besarnya nilai $\mathbf{r}$ & Interpretasi \\
\hline $0,00-0,200$ & Sangat rendah \\
$0,200-0,400$ & Rendah \\
$0,400-0,600$ & Agak Rendah \\
$0,600-0,800$ & Cukup \\
$0,800-1,00$ & Tinggi \\
\hline
\end{tabular}

\section{HASIL PENELITIAN DAN ANALISIS}

Berdasarkan pengolahan data yang telah diuraikan, langkah selanjutnya adalah menyusun analisis data dalam bentuk perhitungan korelasi product moment untuk mengetahui seberapa besar pengaruh metode Kaisa terhadap kemampuan menghafal surat-surat pendek Al-Qur'an dan Hadits pada anak di TK Aisyiyah 17 Jasem Ngoro Mojokerto.

Adapun perhitungan dari data yang diperoleh untuk mengetahui nilai $\mathrm{r}$ dapat dihitung dengan rumus korelasi product moment sebagai berikut:

$$
\begin{gathered}
r_{x y=} \frac{\sum x y}{\sqrt{\left(\sum x^{2} \sum y^{2}\right)}} \\
r_{x y=} \frac{212148}{\sqrt{(105575)(426623)}} \\
r_{x y=\frac{212148}{212227}} \\
r_{x y=0,999}
\end{gathered}
$$

Harga koefisien tersebut selanjutnya diuji siginifikannya dengan membandingkan harga $\mathrm{r}$ tabel. Bila menggunakan $\mathrm{r}$ tabel untuk $\mathrm{n}=11$ an kesalahan $5 \%$ maka $\mathrm{r}$ tabel $=$ 0,602 , sedangkan $\mathrm{r}$ hitung adalah 0,999 . Ketentuan bila $\mathrm{r}$ hitung $<\mathrm{r}$ tabel maka $\mathrm{H}_{0}$ diterima dan $\mathrm{H}_{1}$ ditolak. Tetap sebaliknya bila $\mathrm{r}$ hitung $>\mathrm{r}$ tabel maka $\mathrm{H}_{1}$ diterima. Dari hasil perhitungan ternyata $\mathrm{r}$ hitung $>\mathrm{r}$ tabel maka $\mathrm{H}_{1}$ diterima dan $\mathrm{H}_{0}$ ditolak. $\mathrm{H}_{0}$ yang menyatakan tidak ada "Pengaruh Metode Kaisa terhadap Kemampuan Menghafal SuratSurat Pendek Al-Qur'an dan Hadits" di TK Aisyiyah 17 Jasem Ngoro Mojokerto ditolak.

Besarnya "pengaruh metode Kaisa terhadap kemampuan menghafal surat-surat pendek Al-Qur'an dan Hadits" di TK Aisyiyah 17 Jasem termasuk dalam kategori tinggi, mengingat 0,999 setelah dikonsultasikan dengan nilai koefisien korelasi berada pada nilai $0,800-1,00$.

Melalui teknik angket yang peneliti laksanakan di TK Aisyiyah 17 Jasem melalui pengamatan pada anak-anak yang menunjukkan bahwa kegiatan tahfidz memiliki pengaruh yang sangat tinggi terhadap kemampuan menghafal surat-surat pendek AlQur'an dan Hadits. Hal ini dapat dilihat bahwa anak-anak mampu menyelesaikan target hafalan yang diberikan oleh pendidik dalam rapot tahfidz yang sudah disesuaikan dengan usianya dengan cepat dan mudah dengan hasil yang sangat baik.

Namun, kebenaran hasil penelitian ini tidak hanya dari hasil perhitungan saja, tetapi juga dibenarkan dengan teori pendukung dalam penelitian ini.

Peneliti mengacu dan menyimpulkan dari teori Jean Piaget. Jean Piaget berpendapat bahwa pada umur dua tahun keatas anak mulai menggunakan simbol atau tanda untuk mempresentasikan suatu benda yang tidak tampak dihadapannya. Ia dapat menggambarkan suatu benda atau kejadian yang sudah lalu (Suparno, 2001, p.55). Untuk anak usia 2-7 tahun berada pada tahapan berpikir "Praoperasional." Pada tahap tersebut 
anak tidak dapat memahami sesuatu tanpa dipraktikkan terlebih dahulu (Riyanti, 2014, p.1).

Menurut Ray L. Briwitsel, setiap anggota tubuh seperti wajah (termasuk senyuman dan pandangan mata), tangan, kepala, kaki dan bahkan tubuh secara keseluruhan dapat digunakan sebagai isyarat simbolik karena manusia hidup, semua anggota badan senantiasa bergerak (Mulyana, 2000, p.317).

Menurut Nashr Yasir, masa kanak-kanak adalah masa keemasan bagi anak-anak untuk menghafal Al-Qur'an. Karena menghafal Al-Qur'an pada masa kanak-kanak tersebut sangat cepat dan akan menghasilkan hafalan yang kuat serta tidak mudah lupa. Anak dapat menghafal Al-Qur'an saat ia memasuki usia tiga tahun. Didalam Al-Qur'an terdapat ayat-ayat Makkiyah, yang memiliki cirri-ciri berisi ayat-ayat pendek. Sesuai dengan napas anak-anak yang pendek. Disamping itu surat-suratnya juga pendek, sehingga mudah dihafal tetapi pengaruhnya cukup besar.

Dari teori diatas, hasil analisis data yang dihasilkan sesuai dengan teori tersebut. Bahwa pada umur dua sampai tujuh tahun anak berada pada tahap pra operasional dimana anak kecil secara mental mulai bisa mempresentasikan objek yang tak hadir dengan menggunakan simbol, tanda ataupun isyarat. Pemikiran simbolik berjalan melampaui koneksi-koneksi sederhana dari informasi sensorik dan tindakan fisik. Dengan demikian metode Kaisa, anak dapat melakukan hafalan surat-surat pendek Al-Qur'an dan Hadits dengan cepat dan mudah melalui gerakan tubuh yang dapat menjadikan suasana pembelajaran yang menyenangkan.

\section{SIMPULAN DAN SARAN}

Ada pengaruh metode Kaisa terhadap kemampuan menghafal surat-surat pendek Al-Qur'an dan Hadist anak di TK Aisyiyah 17 Jasem Ngoro Mojokerto, terbukti dari hasil perhitungan statistik serta data yang terkumpul diperoleh angka hitung sebesar 0,999 lebih besar dari angka tabel $\mathrm{N}=11=5 \%=0,602$. Dari angka tersebut, menunjukkan ada pengaruh metode Kaisa terhadap kemampuan menghafal surat-surat pendek Al-Qur'an dan Hadist anak di TK Aisyiyah 17 Jasem Ngoro Mojokerto.

Besarnya pengaruh metode Kaisa terhadap kemampuan menghafal surat-surat pendek Al-Qur'an dan Hadist pada anak di TK Aisyiyah 17 Jasem Ngoro Mojokerto termasuk kategori "tinggi". Karena 0,957setelah dikonsultasikan dengan nilai koefisien korelasi berada pada nilai $0,800-1,00$.

\section{DAFTAR RUJUKAN}

Abdud, A. K. (2010). Hafal Al-Qur'an Tanpa Nyantri. Solo: Pustaka Arafah.

Abdurrahman, J. (2010). ISLAMIC PARENTING Pendidikan Anak Metode Nabi. Solo: Aqwam.

Arikunto, S. (2014). Prosedur Penelitian. Jakarta: Rineka Cipta.

Badwilan, S. A. (2009). Panduan Cepat menghafal Al-Qur'an. Yogyakarta: Diva Press.

Bondowoso, P. (2019, Oktober Sabtu). Subhanallah Lima Bersaudara Cilik ini Hafiz.

Qur'an Asal Makassar. Diambil kembali dari

http://liputanlima.com/lifestyle/2016/02/08/subhanllah-lima-bersaudara-cilik-inihafiz-quran-asal-makassar

Desy, A. (2003). Kamus Lengkap Bahasa Indonesia. Surabaya: Amelia.

Dina, R. N. (2018). Meningkatkan Kemampuan Menghafal Surat-Surat Pendek Melalui Metode Kinestetik Anak Kelompok B TKIT Nuru Islam Pelem Kecamatan Pare Kabupaten Kediri Tahun Ajaran 2016-2017. Vol. 4 Nomor 1 . 
Djaalali, P. M. (2008). Pengukuran dalam Bidang Pendidikan. Jakarta: Grasindo.

Efendi, M. Y. (2011). Ayah Juara 7 Hari Menjadi Ayah Qur'ani. Solo: PT Era Adicitra Intermedia.

Habibi, M. (2018). Analisis Kebutuhan Anak Usia Dini. Yogyakarta: Deepublish.

Indianto, A. (2015). Kiat-kiat Mempertajam Daya Ingat Hafalan Pelajaran. Yogyakarta: DIVA press.

Islam, B. (2019, Oktober Sabtu). Lima Bersaudara ini Hafal Al-Qur'an dengan Metode Unik. Diambil kembali dari www.bersamaislam.com/2016/04/lima-bersuadara-inihafal-quran-dengan.html?m=1

Khadijah. (2016). Perkembangan Kognitif Anak Usia Dini. Medan: Perdana Publishing.

Majdi, U. (2014). 9 Langkah Mudah menghafal Al-Qur'an. Solo: Aqwam.

Majid, A. (2016). Strategi Pembelajaran. Bandung: PT Remaja Rosdakarya.

Malikhah, F. (2019). Penerapan Metode Gerakan untuk Menghafal Hadits pada Anak. , Vol. 4 No. 1.

Mulyana, D. (2000). Ilmu Komunikasi. Bandung: PT Remaja Rosdakrya.

Nashr, Y. (2014). Kecil-Kecil Jadi Hafiz. Solo: As Salam.

Rianti, A. A. (2014). Cara Efektif Mengenalkan Rukun Iman pada Anak. Jakarta: Gramedia.

Ririn. (2019, Oktober Selasa). Begini Cara Kaisa hafiz cilik Lafalkan al-Qur'an dengan Gerakan. Diambil kembali dari http://ramadan.detik.com/read/2014/07/10/beginicara-kaisa-hafiz-cilik-lafalkan-alquran-dengan-gerakan

Romdoni, M. (2014). Metode Cepat menghafal \& Memahami Ayat-Ayat Suci Al-Qur'an. Yogyakarta: Lafal Indonesia.

Saad, R. (2008). Ingin Anak Anda Cinta Al-Qur'an? Solo: Aqwam.

Sa'adullah. (2008). Cara Cepat Menghafal Al-Qur'an. Jakarta: Gema Insani.

Salamah, U. (2003). Pengajaran Menggunakan Metode Kaisa dalam Menghafal AlQur'an pada Anak, Vol. 7 No. 2.

Suaparno, P. (2001). Teori Perkembangan Jean Piaget. Yogyakarta: Penerbit Kanisius.

Sugiono. (2014). Metode Penelitian Pendidikan. Bandung: Alfabeta.

Sukardi. (2003). Metodologi Penelitian pendidikan. Jakarta: Bumu Aksara.

Suroso. (2004). Smart Brain: Metode menghafal Cepat dan Meningkatkan Ketajaman Memori. Surabaya: SIC.

Wowo, K. S. (2012). Taksonomi Kognitif Perkembangan Ragam Berpikir. Bandung: PT Remaja Rosdakarya.

Yahya, G. (2014). Metode Cepat Hafal A-Qur'an. Solo: As-Salam.

\section{AUTHOR}

Try Nur Aliyah Program Studi Pendidikan Guru Pendidikan Anak Usia Dini, Universitas

Muhammadiyah Sidoarjo, Indonesia email trynuraliyah99@gmail.com 